\title{
RECEIVED
}

\section{JAN 301996 \\ Corrosion of Low-Carbon Steel Under Environmental Conditions at Hanford: Two-Year Soil Corrosion Test Results}

Prepared for the U.S. Department of Energy Office of Environmental Restoration and Waste Management

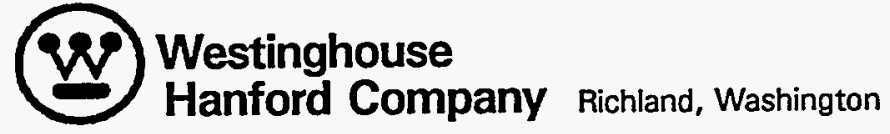

Management and Operations Contractor for the U.S. Department of Energy under Contract DE-AC06-87RL10930 
LEGAL DISCLAIMER

This report was prepared as an account of work sponsored by an agency of the United States Government. Neither the United States Government nor any agency thereof, nor any of their employees, nor any of their contractors, subcontractors or their employees, makes any warranty, express or implied, or assumes any legal liability or responsibility for the accuracy, completeness, or any third party's use or the results of such use of any information, apparatus, product, or process disclosed, or represents that its use would not infringe privately owned rights. Reference herein to any specific commercial product, process, or service by trade name, trademark, manufacturer, or otherwise, does not necessarily constitute or imply its endorsement, recommendation, or favoring by the United States Government or any agency thereof or its contractors or subcontractors. The views and opinions of authors expressed herein do not necessarily state or reflect those of the United States Government or any agency thereof.

This report has been reproduced from the best available copy. Available in paper copy and microfiche.

Available to the U.S. Department of Energy and its contractors from

Office of Scientific and Technical Information

P.O. Box 62

Oak Ridge, TN 37831

(615) 576-8401

Available to the public from the U.S. Department of Commerce National Technical Information Service 5285 Port Royal Rogd

Springfield, VA 22161

(703) 487-4650

Printed in the United States of America

DISCLM-1.CHP (1-91) 


\section{Corrosion of Low-Carbon Steel Under Environmental Conditions at Hanford: Two-Year Soil Corrosion Test Results}

R. P. Anantatmula

Westinghouse Hanford Company

J. R. Divine

ChemMet Ltd., PC

Date Published

November 1995

Prepared for the U.S. Department of Energy Office of Environmental Restoration and Waste Management

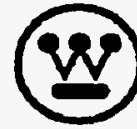




\section{RELEASE AUTHORIZATION}

\section{Document Number: $\quad$ HHC-EP-0891}

Corrosion of Low-Carbon Steel Under Environmental

Document Title: Condition at Hanford: Two-Year Soil Corrosion Test Results

Release Date: $\quad 12 / 6 / 95$

This document was reviewed following the procedures described in WHC-CM-3-4 and is:

APPROVED FOR PUBLIC RELEASE

WHC Information Release Administration Specialist:

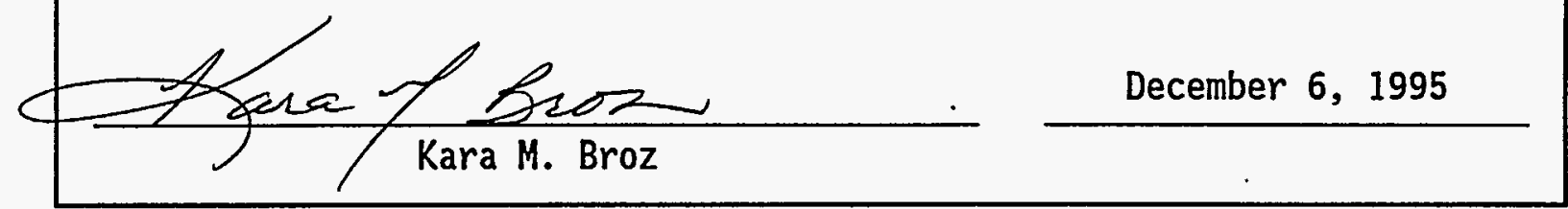




\section{Corrosion of Low-Carbon Stee1}

Under Environmental Conditions at Hanford:

Two-Year Soil Corrosion Test Results

R. P. Anantatmula

Westinghouse .Hanford Company

J. R. Divine

ChemMet Ltd., PC

Prepared for the U. S. Department of Energy

office of Environmental Restoration and Waste Management

Westinghouse Hanford Company

P. 0. Box 1970

- Richtand, Washington 99352 
WHC-EP-0891

\author{
Corrosion of Low-Carbon Steel \\ Under Environmental Conditions at Hanford: \\ Two-Year Soil Corrosion Test Results
}

\title{
1. INTRODUCTION
}

At the Hanford Site, located in southeastern Washington state, nuclear production reactors were operated from 1944 to 1970. The handling and processing of radioactive nuclear fuels produced a large volume of low-level nuclear wastes, chemical wastes, and a combination of the two (mixed wastes). These materials have historically been packaged in U.S. Department of Transportation (DOT) approved drums made from low-carbon steel, then handled in one of three ways:

A. Before 1970, the drums were buried in the dry desert soil. It was assumed that chemical and radionuclide mobility would be low and that the isolated, government-owned site would provide sufficient protection for employees and the public.

B. After 1970 , the drums containing long-lived transuranic radionuclides were protected from premature failure by stacking them in an ordered array on an asphalt concrete pad in the bottom of a burial trench. The array was then covered with a large, $0.28-\mathrm{mm}-\left(011-\mathrm{in}_{-}-\right)$thick polyethylene tarp and the trench was backfilled with $1.3 \mathrm{~m}(4 \mathrm{ft})$ of soil cover. This burial method is referred to as soil-shielded burial. Other configurations were also employed but the soil-shielded burial method contains most of the transuranic drums.

C. Since 1987, US Department of Energy sites have complied with the Resource Conservation and Recovery Act of 1976 (RCRA) regulations. These regulations require mixed waste drums to be stored in RCRA compliant large metal sheds with provisions for monitoring. These sheds are provided with forced ventilation but are not heated or cooled.

The current drums meet DOT Type $17 \mathrm{H}$ or $17 \mathrm{C}$ specifications. The most recent drums al so meet the new DOT performance-based packaging standards. The 208-L (55-ga7) drums are liquid-tight through use of gaskets and sealants and are painted with a chemically resistant epoxy on the outer surfaces. A bolted ring securely attaches the lids of these drums.

To determine how long waste materials might reasonably be contained and how much corrosion might be present during planned retrieval efforts for certain waste classes, the corrosion rate of low-carbon steel in the environments associated with the three types of drum storage outlined above must be determined.

Westinghouse Hanford Company (WHC), in collaboration with the Pacific Northwest Laboratory (PNL), initiated corrosion experiments on drum material coupons a) exposed to the atmosphere in large metal storage sheds and b) buried in Hanford soil, simulating the environmental conditions expected during storage as described in storage methods $A$ to $C$ above (Bunnell et al., 1994). This report 
focuses only on the experiments performed simulating the burial of drums deep in the Hanford soil, as described in the storage method A above.

The soil corrosion experiments were initiated in 1993 with exposure times ranging from $0.5 \mathrm{yr}$ to $16 \mathrm{yrs}$. The experiments included specimens of bare carbon steel, painted carbon steel, painted and damaged carbon steel (to simulate the corrosion of both non-damaged and damaged drums), and alternative materials, viz., ga7vanized carbon stee 1 and AISI Type 304L stainless steel (304L). Corrosion coupons exposed for $0.5 \mathrm{yr}$ (actual time of exposure was $0.75 \mathrm{yr}$ ) and $1 \mathrm{yr}$ were retrieved from the soil in 1994 and evaluated for corrosion (Duncan and Bunne11, 1995). The present report describes the results obtained on corrosion coupons exposed to Hanford soil for 2 yrs.

\section{EXPERIMENTAL METHOD}

A total of six shafts (five peripheral shafts for specimens and a central shaft for instrumentation) were drilled in 1993 to accommodate burial times of up to 16 yrs. The original plan was to drill six circumferential shafts surrounding the central shaft in a hexagonal pattern. Figure 1 outlines the planned. retrieval times, differing by factors of two, and the shaft layout. As indicated in the figure, the sixth circumferential shaft was not drilled. Instead, after the 1-yr specimens were removed from the 1-yr shaft in JuTy 1994, 16-yr specimens were placed in the same shaft to avoid the expense of decommissioning the shaft and drilling a new shaft. Details of instrumentation in the central shaft were described by Bunnell et al. (1994) previously.

Specimens measuring $2.5-\mathrm{cm}$ by $6-\mathrm{cm}$ (1-in. by $4-i n$.$) of bare carbon steel, painted$ steel, damaged painted stee $1,304 \mathrm{~L}$, and galvanized steel were emplaced at known depths to $9.1 \mathrm{~m}(30 \mathrm{ft})$. The specimens were attached with nylon screws to hexagonal polyethylene blocks to avoid galvanic corrosion. One specimen of each type at each of four depths, for six planned retrieval times for a total of 24 duplicate specimens were emplaced. Figure $2 a$ shows a hexagonal block with specimens installed. To protect specimens from damage during retrieval drilling, these specimen blocks were inserted into $0.6-\mathrm{m}(2-\mathrm{ft})$ lengths of slotted polyvinyl chloride (PVC) casing (see Figure 2b). During specimen emplacement, soil removed from the intended burial depth was carefully packed around the hexagonal block inside the casing, and the assemblies were lowered into shafts drilled to the desired depths. Ground vibrations associated with extraction of drit1 casings are assumed to have packed the surrounding soil to a density approaching undisturbed soil.

Specimens were retrieved by using a core-barrel dritling rig, in which a heavy-walled steel pipe was driven into the soil and then pulled to the surface with the soil column it contained. The pipe was oversized relative to the original shaft diameter of $30 \mathrm{~cm}$ (12 in.); the original shafts were drilled within $5 \mathrm{~cm}$ (2 in.) of plumb over their length. Thus, the retrieval technique was to simply redrill the original shaft at a s7ightly larger diameter to ensure the specimens would be captured. 
WHC-EP-0891

\section{RESULTS AND DISCUSSION}

To summarize previous retrievals, the nominal 6-mo retrieval was accomplished in March 1994, after an actual exposure time of 9 months. Specimens located 1.5 and $3 \mathrm{~m}(5$ and $10 \mathrm{ft}$ ) below grade were retrieved easi7y. Those at the $6.1-\mathrm{m}(20-\mathrm{ft})$ level were more difficult to retrieve; one specimen was lost and others were damaged. The soil around the specimens at the $9.1-\mathrm{m}(30-\mathrm{ft})$ level was very dry, which made it difficult to pul1 to the surface. Smaller-bore core barrels were tried, but the specimens and their plastic carrier were destroyed. Retrieval of the 1-yr specimens was accomplished in Ju7y 1994, but once again one of the specimen sets (buried 1.5-m deep) was destroyed during drit1ing.

The retrieval of the 2-yr specimens was performed on September 20 and 21, 1995. A11 specimens were retrieved. The major variation that occurred was that no specimens were found at $1.5-\mathrm{m}(5-\mathrm{ft})$. Instead, specimens were found at $3-\mathrm{m}$, 4.6-m, 6.1-m, and 9.1-m (10-ft, 15-ft, 20-ft, and 30-ft). No indication has been found in the records as to why this placement of coupons occurred.

During retrieval, it was observed that the soil at about 0.6 to $1-\mathrm{m}$ was extremely wet. Below that the soil was much drier with the driest soil between about 3and $6-\mathrm{m}$. Below that it had a noticeable moisture content but not to the degree noted earlier. These observations are considered consistent with the cooler, wetter summer experienced in 1995 . The soil from $0^{\prime}$ to $14^{\prime}$ contained medium size cobbles, gravel and brown sand. The soil from $14^{\prime}-15^{\prime}$ depth consisted of brown sand and a small amount of silt. The soil retrieved from $14^{\prime}-30^{\prime}$ depth again contained a small amount of silt with lighter brown sand.

After retrieval, specimens were photographed mounted on their polyethylene blocks, then removed and examined. Specimens of bare Tow-carbon steel and 304L were cleaned of corrosion products by using inhibited hydrochloric acid. Specimens were dried and then weighed to determine the amount of metal lost to corrosion.

Table 1 presents the 2-yr exposure results and Table 2 shows the summary of results to date. Based on the 2-yr data, weight-loss measurements indicated that bare low-carbon steel was corroded by contact with the soil at rates from 15.2 to $35.6 \mathrm{microns}(\mu \mathrm{m}) / \mathrm{yr}(0.6$ to $1.4 \mathrm{mi} / \mathrm{yr}[\mathrm{mpy}])$. These values 7 ie between the extremes observed at 9-mo and s7ight7y higher than the values observed at 1-yr. As mentioned earlier, the 2-yr specimens were retrieved from $10^{\prime}, 15^{\prime}, 20^{\prime}$ and $30^{\prime}$ depths. If we assume that the 9 -month and $1-y r$ specimens were al so located at the same depths (instead of $5^{\prime}, 10^{\prime}, 20^{\prime}$ and $30^{\prime}$ depths as reported previous $7 y$ ), the agreement in corrosion rates between the 3 sets of measurements for bare carbon steel is much better.

Weight-loss measurements also indicated that 304L was not corroded to a measurable extent in the 2-yr exposure.

The bare low-carbon steel displayed a rough surface typical of underground corrosion after 2-yr of exposure (see Figure 3 ). The specimen located at 3-m had one spot on an edge that might be indicative of pitting but the location on the 
edge of the specimen prevented any determination of depth. From the appearance of the uncleaned specimens, this was the only carbon steel specimen that may have actually pitted.

The 304L coupons showed no signs of pitting with the exception of the one at 9.1-m. It had smal1 pits, 13- to 38- $\mu \mathrm{m}$ (0.5- to 1.5-mils) deep, at the bottom end of the coupon on the back. Therefore, it is likely that it was due to crevice corrosion.

The last column of Table 2 shows corrosion rates of low-carbon steel as indicated by electrical resistance probes placed at various soil depths in the central shaft (see Figure 1) located at about $6.1 \mathrm{~m}(20 \mathrm{ft}$ ) from the shaft from which the 2-yr specimens were extracted. These measurements indicate that corrosion rates varied with depth and ranged from about 25 to $50 \mu \mathrm{m} / \mathrm{yr}$ ( 1 to $2 \mathrm{mpy}$ ). This is the same general range as that measured by weight-loss methods. However, the correlation at various depths varied, with the probes running typically 13 to 25 $\mu \mathrm{m} / \mathrm{yr}$ ( 0.5 to $1 \mathrm{mpy}$ ) higher than the coupons. Because the coupons showed a rough texture of the corroded surface, it is assumed the probes also underwent a similar variability in corrosion on each coupon. As a consequence, it is reasonable to assume that the $125 \mu \mathrm{m}$ ( $5 \mathrm{mil}$ ) thick steel foil has been penetrated in some locations which would effectively raise the resistance of the probe and indicate a higher resistance. On this basis, in accordance with the original design, the probes should start to fail in the near future. Nevertheless, both sets of data showed a trend of decreasing corrosion rates with depth and do not give contradictory results.

Upon initial examination, some painted low-carbon steel specimens showed paint damage in small areas, but lack of corrosion on the steel surfaces indicated that the damage occurred by mechanical means during retrieval. There were several other small areas showing degradation, possibly indicating some damage despite care during installation. The epoxy paint used on the drum metal is strong but quite brittle and is subject to damage when contacted by hard objects such as rocks.

Even after 2-yr, the damaged painted steel specimens showed very little corrosion of the exposed steel, and paint lifting had not occurred at the paint-steel interface. Corrosion was apparently too localized to spread laterally or lift paint. These characteristics are likely to be observed in specimens exposed for Tonger periods.

The galvanized steel specimens at the two upper levels were black suggesting corrosion is in process. The two lower level specimens showed only slight and uniform dulling of the surface, suggesting that little zinc was lost to corrosion.

The 304L specimens showed no visible corrosion; pitting occurred only on the lowest specimen. It occurred only on the back of the coupon and appears to be more of a case of crevice corrosion even though very localized. 


\section{CONCLUSIONS}

1. After two years of exposure to soil at the Hanford Site, bare low-carbon steel appears, by both weight-Toss measurements and electrical resistance probes, to be corroding at about 15 to $35 \mu \mathrm{m} / \mathrm{yr}$ ( 0.6 to $1.4 \mathrm{mpy})$. In genera1, the carbon steel corrosion rate decreases with increasing depth.

2. The 304L corrodes at a much lower rate than low carbon steel, 0.08 to 0.2 $\mu \mathrm{m} / \mathrm{yr}$ ( 0.003 to $0.008 \mathrm{mpy}$ ) in Hanford soil and shows some pitting, $13 \mu \mathrm{m}$ to $38 \mu \mathrm{m}$ ( 0.5 to $1.5 \mathrm{mil})$ deep after two years of exposure on the deepest specimen.

5. SUMMARY

Tests are presently under way to measure the corrosion of bare low-carbon steel, painted low-carbon steel, painted and damaged low-carbon steel, and possible alternative container materials. The tests focus on attacks by either the atmosphere or by soil at the Hanford Site. Alternative materials include galvanized steel and 304L. Both of these tests include sensors to characterize the environment surrounding the exposed specimens.

Soil corrosion is proceeding at a measurable and approximately constant rate on low-carbon stee 7 . This rate ranges from 15 to $35 \mu \mathrm{m} / \mathrm{yr}$ (0.6 to $1.4 \mathrm{mpy})$ and decreases with increasing depth. The 304L corrodes at less than $1 \mu \mathrm{m} / \mathrm{yr}$ in the soil environment but appears to suffer some crevice attack on the deepest specimen.

In general, corrosion has occurred at a very low rate in both carbon steel and 304L, reflecting the relatively benign and dry environments at the Hanford Site. The corrosion rates are less than those suggested by previous work as summarized by Divine (1991). These results are applicable to other direct buried steels at the Hanford Site, viz., transfer lines, burial boxes etc.

\section{REFERENCES}

Copson, H. R., "A Theory of the Mechanism of Rusting of Low Alloy Steels in the Atmosphere, "Proc. ASTM, 45, 544 (1945).

Bunne 11, L. R., Doremus, L. A., Topping, J. B., Duncan, D. R., Task E Container Corrosion Studies: Annual Report, WHC-EP-0769, June 1994.

Duncan, D. R., Bunne11, L. R., Measurements of the Corrosion of Low-Carbon Steel Drums Under Environmental Conditions at Hanford: One-Year Test Results, WHC EP 0859, May 1995.

Divine, J. R., A Review of the Hanford Site Soil Corrosion Applicable to Solid Waste Containers, WHC-EP-0408, May, 1991. 


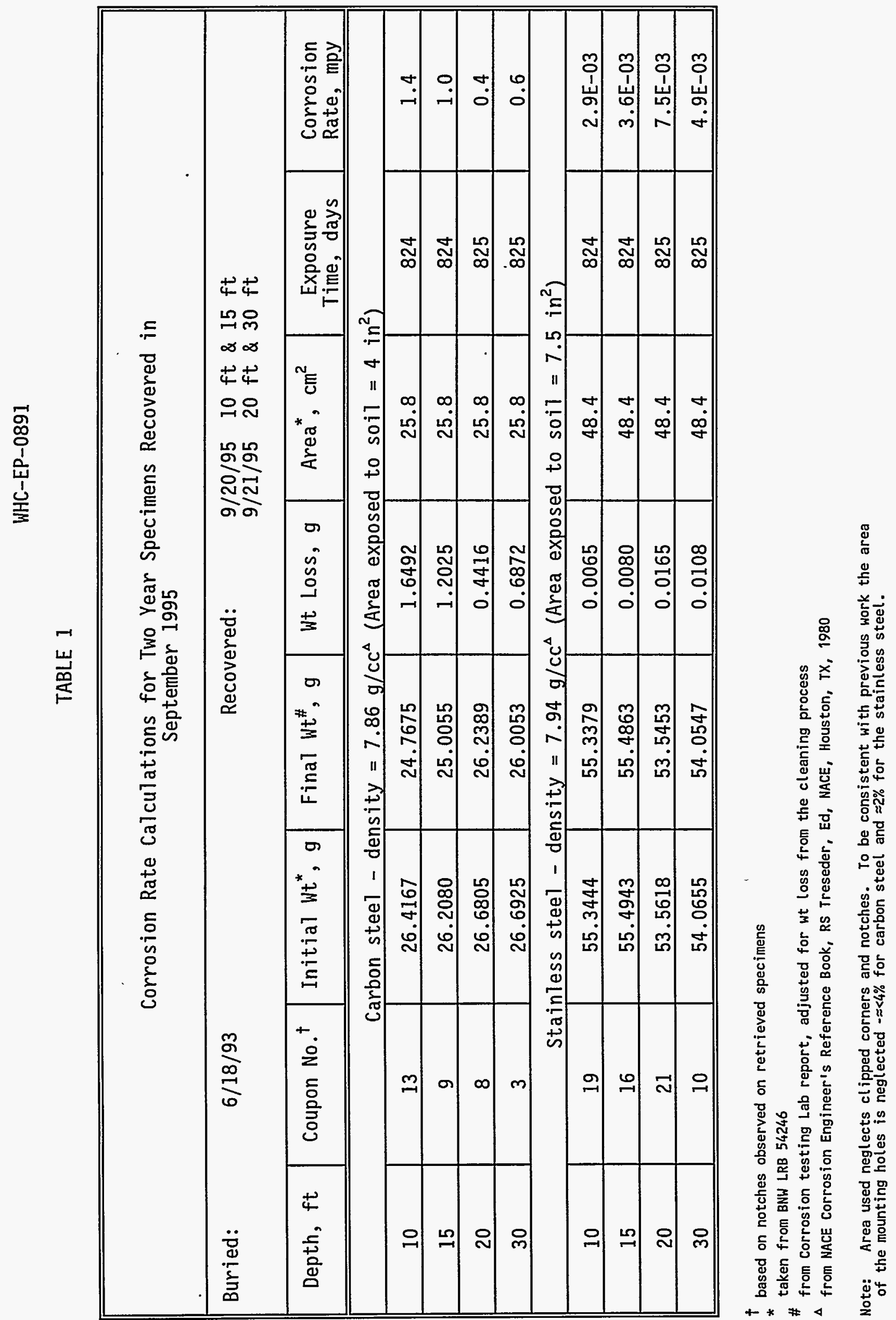


TABLE 2

\begin{tabular}{|c|c|c|c|c|c|}
\hline \multicolumn{6}{|c|}{ Comparison of 2-yr Data with 9-mo and 1-yr Data } \\
\hline $\begin{array}{l}\text { Depth } \\
\text { (ft) }\end{array}$ & \multicolumn{5}{|c|}{$\begin{array}{c}\text { Corrosion Rate } \\
\text { (mpy) }\end{array}$} \\
\hline$\cdot$ & 9-mo & $1-y r$ & $2-y r$ & Average & Probes \\
\hline \multicolumn{6}{|c|}{ Carbon Steel } \\
\hline 5 & 1.7 & & & 1.7 & 2.1 \\
\hline 10 & 0.9 & 1.0 & 1.4 & 1.1 & 2.1 \\
\hline 15 & & & 1.0 & 1.0 & \\
\hline 20 & 0.3 & 0.6 & 0.4 & 0.4 & 1.5 \\
\hline 30 & & 0.2 & 0.6 & 0.4 & 0.9 \\
\hline \multicolumn{6}{|c|}{ Stainless Steel } \\
\hline 5 & 0.0065 & & & 0.0065 & \\
\hline 10 & 0.0096 & 0.0210 & 0.0029 & 0.0112 & \\
\hline 15 & & & 0.0036 & 0.0036 & \\
\hline 20 & & 0.0180 & 0.0075 & 0.0127 & \\
\hline 30 & & 0.0190 & 0.0049 & 0.0119 & \\
\hline
\end{tabular}




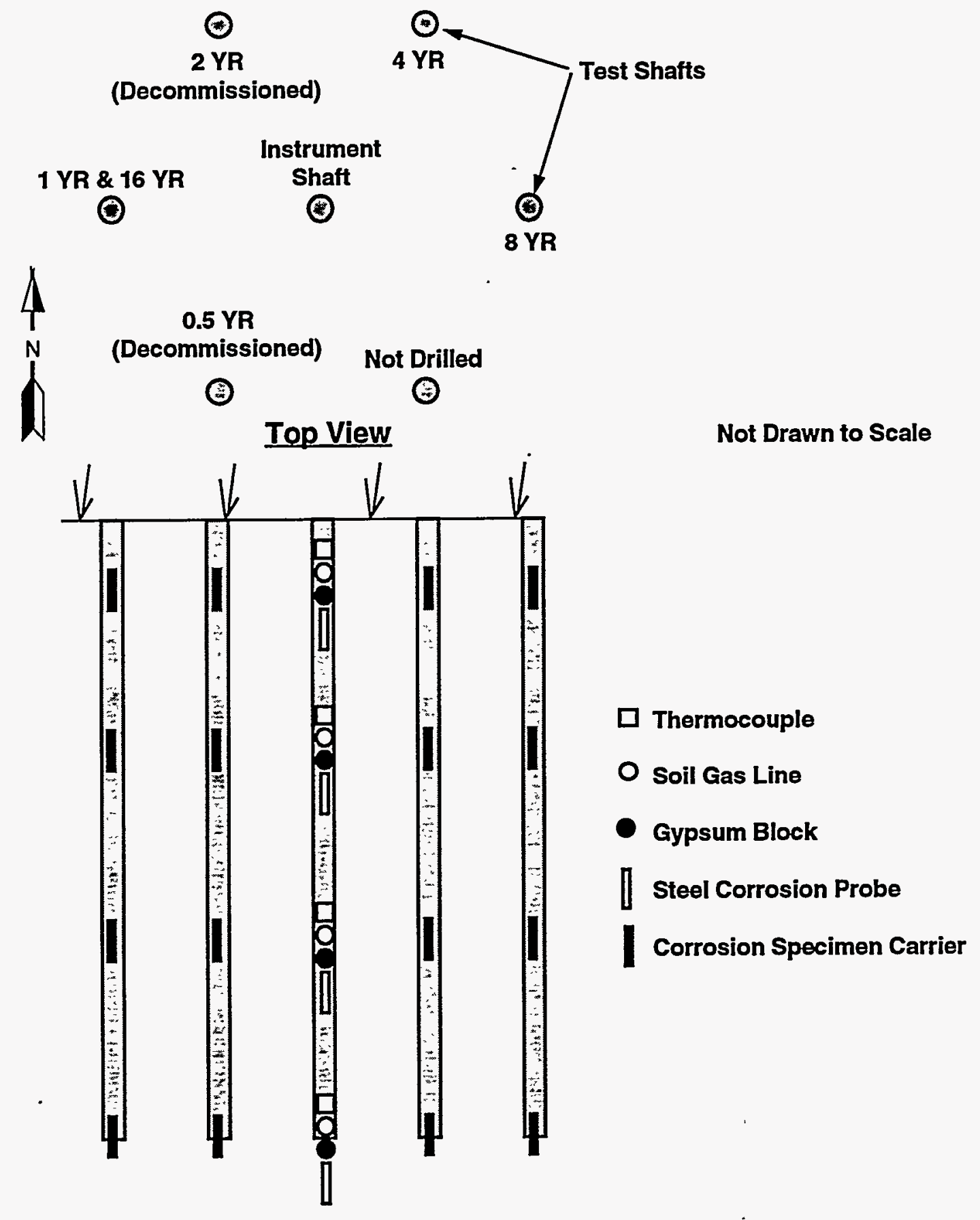

Side View

2G95100439.1

Figure 1. Shaft Layout Showing Instrumentation and Retrieval Schedule 


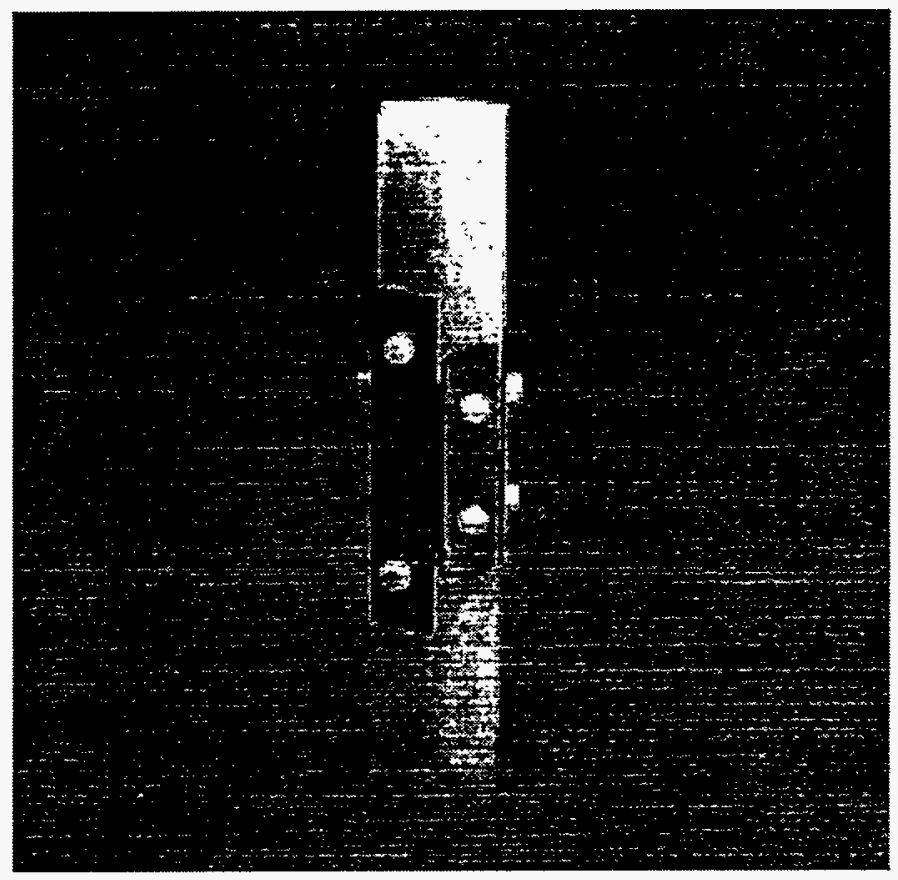

a. Specimens Attached to Polyethylene Block

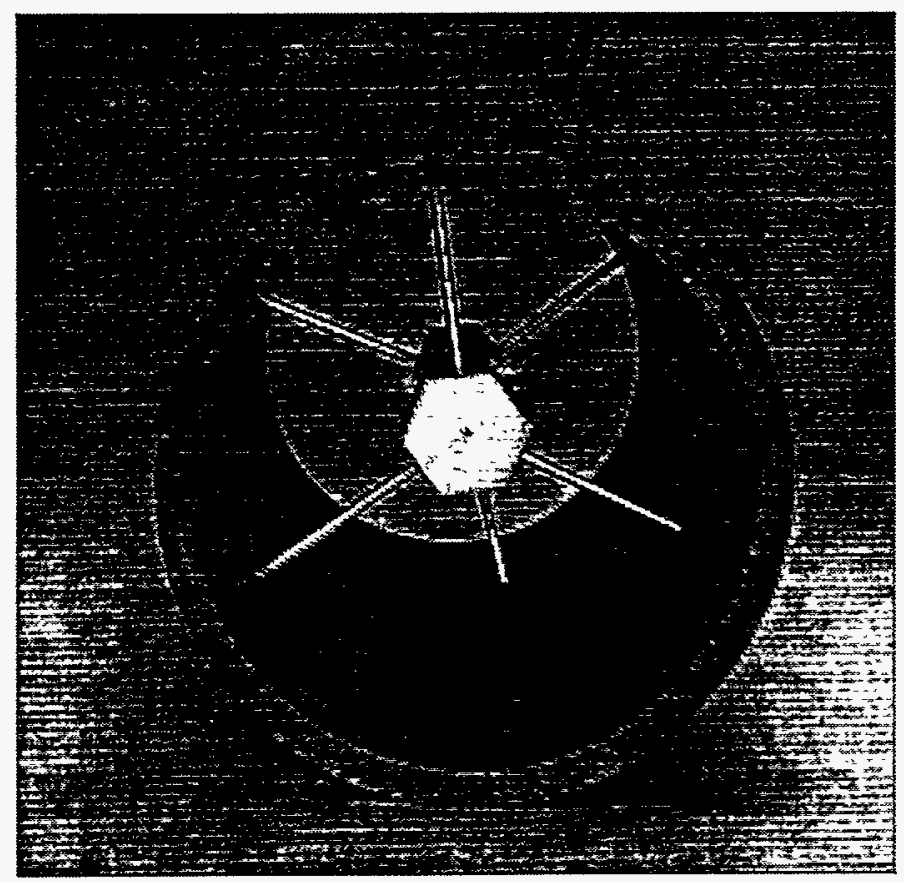

b. Polyethylene Block (with Specimens) Mounted in PVC Pipe, Ready for Burial

2G95110079.1

Figure 2. Specimen Assembly Prior to Burial in Soil 


\section{Bare Carbon Steel 9-20-95, $10 \mathrm{ft}$ Depth Front Surface (Exposed to soil)}

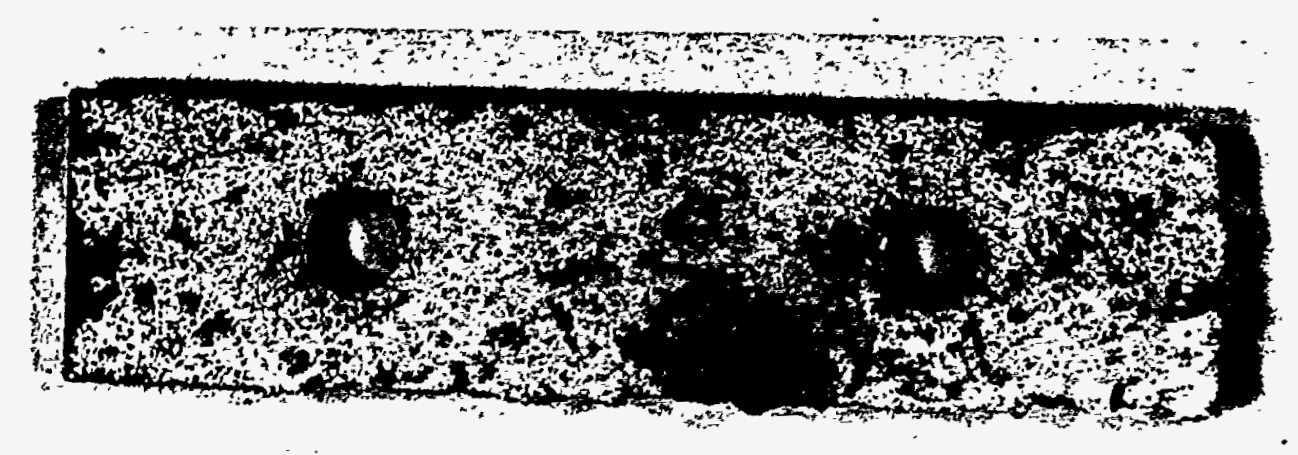

\section{Bare Carbon Steel 9-20-95, $10 \mathrm{ft}$ Depth Back Surface (In contact with specimen holder)}

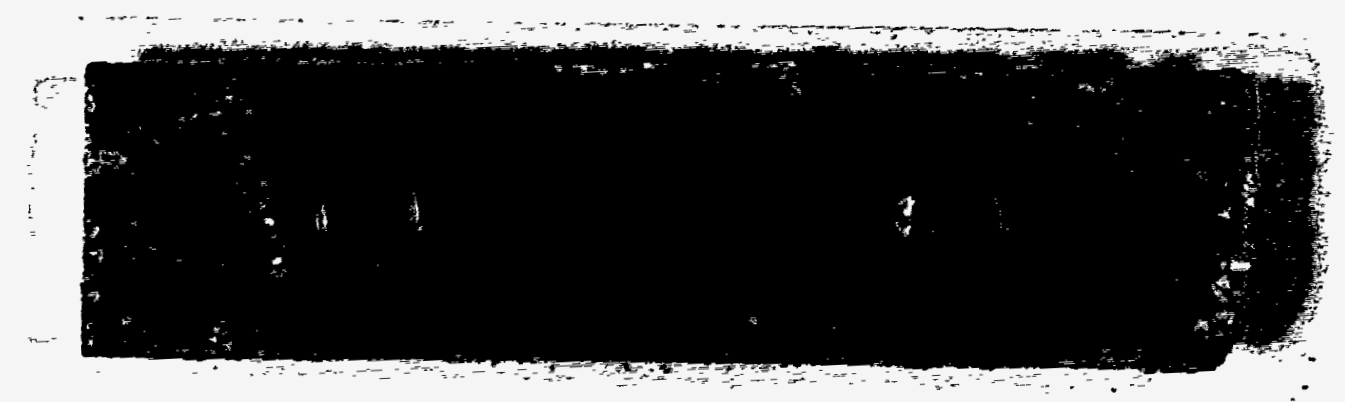



R. P. Anantatmula (10) R1-30
R. A. Bilskis
$\mathrm{R} 2-88$
D. R. Duncan
R3-86
C. R. Eiholzer
HO-36
J. H. Haberman
R1-30
D. C. Lindsay
$\mathrm{R} 1-30$
F. M. Mann
HO-36
P. C. Oh1
R1-30
J. G. Riddelle
T3-01
H5-52
H5-52
R2-54
H5-52
A3-88
E6-44
R1-20
TFIC
Central Files (2)
O. S. T. I. (2)
E. J. Watter

Off-Site

J. R. Divine (2)

ChemMet, Ltd., PC

P.0. Box 4068

West Richland, WA 99353-0017

J. E. Marra

Westinghouse Savannah River Company Aiken, SC 29841

Jirna Banaee

INEL

Lockheed Martin Idaho Technologies P.0. Box 1625

Idaho FaTls, ID 83415-3509 